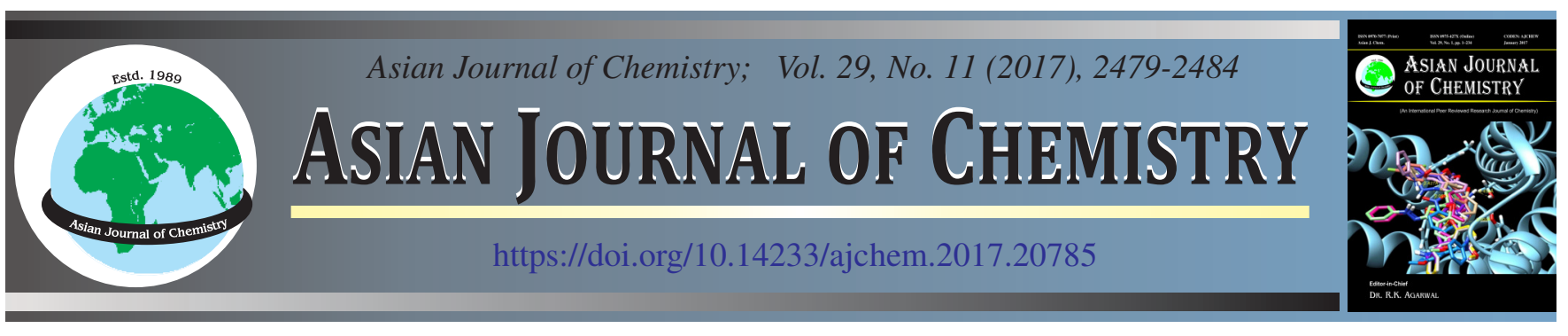

\title{
Microwave Assisted Synthesis, Characterization, Molecular Docking, Antiinflammatory and Analgesic Activity of Acylhydrazones Bearing Thiophene Moiety
}

\author{
M. SOUJANYA ${ }^{1, *}$ and G. RAJITHA ${ }^{2}$
}

${ }^{1}$ Department of Pharmaceutical Chemistry, Gokula Krishna College of Pharmacy, SPSR Nellore-524 121, India

${ }^{2}$ Department of Pharmaceutical Chemistry, Institute of Pharmaceutical Technology, Sri Padmavathi Mahila Visvavidyalayam (Mahila University), Tirupati-517 502, India

*Corresponding author: E-mail: soujipharma@gmail.com

Received: 17 May 2017;

Accepted: 17 August 2017;

Published online: 29 September 2017;

AJC-18576

NSAIDS are the first drug of choice in the treatment of inflammation has several side effects and still there is a need to introduce a new effective agent. In the present study, $\mathrm{N}$-acylhydrazones bearing thiophene moiety were synthesized by applying bioisosterism drug design tool, characterized, screened for anti-inflammatory, analgesic activity and molecular docking using GLIDE. All the compounds viz.,

2-benzamido-N'-(substituted)-3-(thiophen-2-yl)acrylohydrazides (4a-l) were synthesized by the microwave irradiation of compound

2-(benzamido)-3-(thiophen-2-yl)acrylohydrazide (3) with different aromatic/heteroaromatic aldehydes in acidic conditions by microwave irradiation and characterized by IR, ${ }^{1} \mathrm{H} \&{ }^{13} \mathrm{C}$ NMR, Mass spectra, followed by elemental analysis. Compound $\mathbf{4 j}$ showed slightly superior anti-inflammatory and analgesic activity (76 and $64 \%)$ than standard $(73 \%, 62 \%)$. The above results were supported by molecular docking studies done by using COX-2 protein revealed, compound (4j,4d) have $-\mathbf{9 . 7 7},-9.58$ as docking score which is higher than standard (-7.18). The present study concludes the potentiality of acylhydrazones to further developed as effective anti-inflammatory agents.

Keywords: Acylhydrazones, Anti-inflammatory activity, Analgesic activity, Molecular docking, Bioisosterism.

\section{INTRODUCTION}

Inflammation is the complex defense mechanism of body in different pathological such as arthritis, asthma, inflammatory bowel diseases. The therapeutic option for the treatment of inflammation is the conventional NSAIDS but suffers with the gastric pain [1] and cardiac toxicity [2]. So there is a significant need for the development of safer drug, which is devoid from classical side effects. On the other hand hydrazones are the versatile molecule has wide range of biological activities viz. antimicrobial [3], anti-inflammatory [4,5], antitubercular [6,7], anticancer [8], anti HIV [9], analgesic [10], antiamoebic [11] etc. Particularly hydrazone moiety attached to heterocyclic systems was shown to offer enhanced activity [12] and also the heterocyclic system plays an important role in drug development of anti-inflammatory agents [13]. This is achieved by the application of bioisosterism, one of the powerful drug design tool includes the exchange of one of bioisoster with the other to modify the activity profile of lead compound. Against the above background it has been planned to synthesize new acylhydrazone derivatives from the $\mathrm{N}$-( $\alpha$-acetamido cinnamoyl)arylhydrazones [14] by the bioisosteric replacement of phenyl with thiophene and screened for anti-inflammatory, analgesic and molecular docking studies against COX-2 protein (pdb code: 5F19).

\section{EXPERIMENTAL}

All the melting points reported in this series were determined in open capillaries using Thermonik Pricision Melting Point Cum Boiling Point Apparatus C-PMB and are uncorrected. Homogeneity of the compounds was checked by using pre coated TLC plates. The IR spectra were recorded using $\mathrm{KBr}$ pellets on a Perkin-Elmer 1760 Spectrophotometer. ${ }^{1} \mathrm{H},{ }^{13} \mathrm{C}$ NMR spectra were recorded on Bruker Advance/Jeol $400 \mathrm{MHz}$ spectrophotometer, using tetra methyl saline as internal standard. Mass spectra were recorded on an Apex Mass spectrophotometer, elemental analyses were performed on Flash EA1112 CHNS analyzer and microwave irradiation was carried out in a domestic microwave oven (LGMS, $2.45 \mathrm{MHz}$ ). All the solvents and chemicals were procured from Sigma Aldrich and used without purification.

Synthesis of 2-Phenyl-4-[(thiophen-2-yl)methylene] oxazol-5-one (2): Synthesis of 2-phenyl-4-[(thiophen-2-yl)- 
methylene]oxazol-5-one was done accordance with the previously reported method [15].

Synthesis of 2-(benzamido)-3-(thiophen-2-yl)-acylohydrazide (3): 2-Phenyl-4-((thiophen-2-yl)methylene)oxazol5 -one $(2,0.01 \mathrm{mmol})$ was stirred with a solution of hydrazine hydrate $(0.02 \mathrm{mmol})$ in ethanol $(20 \mathrm{~mL})$ for $30 \mathrm{~min}$. The deep yellow colour of oxazolone immediately changed to light yellow colour product, which was filtered, washed, used in next step [16]. Yield: $79 \%$; m.p.: $155-157{ }^{\circ} \mathrm{C}$; IR $\left(\mathrm{KBr}, \mathrm{v}_{\max }, \mathrm{cm}^{-1}\right)$ : 3228, $3242\left(\mathrm{NH}_{2}\right), 3073(\mathrm{Ar} \mathrm{C}-\mathrm{H}) 1651(\mathrm{C}=\mathrm{O}), 1573(\mathrm{C}=\mathrm{N})$; ${ }^{1} \mathrm{H}$ NMR (400 MHz, DMSO-d $\left.d_{6}\right) \delta: 4.45$ (s, 2H, NH $\mathrm{NH}_{2}$, 6.987.99 (m, 9H, Ar C-H, HC=C), 9.73 (s, 1H, CO-NH-C), 10.66 (s, 1H, CO-NH-N); Anal. calcd. for $\mathrm{C}_{14} \mathrm{H}_{13} \mathrm{~N}_{3} \mathrm{O}_{2} \mathrm{~S}(\%)$ : C, 58.52; H, 4.56, N, 14.62. Found: C, 58.17; H, 4.24; N, 17.53.

General procedure for the synthesis of 2-benzamido-N'(substituted)-3-(thiophen-2yl)acrylohydrazide (4a-1): Equimolar ratios of $\alpha$-benzamido-(4-nitro)-cinnamal-hydrazide and different benzaldehydes $(0.01 \mathrm{~mol})$ in absolute ethanol with a few drops of glacial acetic acid were transferred in to reaction flask and allowed to microwave irradiation at 160 watts with $15 \mathrm{~s}$ of interval for about $60-180 \mathrm{~s}$. The reaction was monitored by TLC and the mixture was allowed to cool at room temperature, filter and purified by recrystallization from methanol. The physical data of all the title compounds were given below:

2-Benzamido-N'-(benzylidene)-3-(thiophen-2-yl)acrylohydrazide (4a): Yield: $71 \%$; m.p.: 210-212 ${ }^{\circ} \mathrm{C}$; IR (KBr, $v_{\max }$, $\left.\mathrm{cm}^{-1}\right)$ : $3290(\mathrm{~N}-\mathrm{H}), 3103(\mathrm{Ar} \mathrm{C}-\mathrm{H}), 1637(\mathrm{C}=\mathrm{O}), 1567(\mathrm{C}=\mathrm{N})$; ${ }^{1} \mathrm{H}$ NMR (400 MHz, DMSO- $d_{6}$ ) $\delta: 7.09-8.11$ (m, 14H, Ar C$\mathrm{H}, \mathrm{HC}=\mathrm{C}), 8.42(\mathrm{~s}, 1 \mathrm{H}, \mathrm{HC}=\mathrm{N}), 9.93(\mathrm{~s}, 1 \mathrm{H}, \mathrm{CO}-\mathrm{NH}), 11.59$ (s, $1 \mathrm{H}, \mathrm{CO}-\mathrm{NH}-\mathrm{N}) ;{ }^{13} \mathrm{C}$ NMR $\left(100 \mathrm{MHz}, \mathrm{DMSO}-d_{6}\right): \delta 115$, $127,128,129,130,132,133,147,163,165$. EI-MS m/z; 375 $\left(\mathrm{M}^{+}\right)$. Anal. calcd. for $\mathrm{C}_{21} \mathrm{H}_{17} \mathrm{~N}_{3} \mathrm{O}_{2} \mathrm{~S}(\%)$ : C, 67.18; H, 4.56; N, 11.19. Found: C, 67.34; H, 4.64; N, 11.22.

2-Benzamido-N'-(4-methoxybenzylidene)-3-(thiophen2-yl)acrylohydrazide (4b): Yield: 68 \%; m.p.: 220-222 ${ }^{\circ} \mathrm{C}$; IR $\left(\mathrm{KBr}, \mathrm{V}_{\max }, \mathrm{cm}^{-1}\right): 3255(\mathrm{~N}-\mathrm{H}), 3068$ (Ar C-H), 2836 $\left(-\mathrm{OCH}_{3}\right), 1640(\mathrm{C}=\mathrm{O}), 1577(\mathrm{C}=\mathrm{N}) ;{ }^{1} \mathrm{H}$ NMR $(400 \mathrm{MHz}$, DMSO- $\left.d_{6}\right) \delta 3.76\left(\mathrm{~s}, 3 \mathrm{H}, \mathrm{Ar}-\mathrm{OCH}_{3}\right), 6.96-8.08(\mathrm{~m}, 13 \mathrm{H}, \mathrm{Ar}$ $\mathrm{C}-\mathrm{H}, \mathrm{HC}=\mathrm{C}), 8.33$ (s, 1H, HC=N), 9.89 (s, 1H, CO-NH), 11.42 (s, 1H, CO-NH-N); Anal. calcd. for $\mathrm{C}_{22} \mathrm{H}_{19} \mathrm{~N}_{3} \mathrm{O}_{3} \mathrm{~S}(\%)$ : C, 65.18; H, 4.56; N, 11.19. Found: C, 65.33; H, 4.41; N, 11.53.

2-Benzamido-N'-(4-hydroxy-3-methoxybenzylidene)3-(thiophen-2-yl)acrylohydrazide (4c) Yield: $70 \%$; m.p.: 230-232 ${ }^{\circ} \mathrm{C}$; IR (KBr, $\left.v_{\max }, \mathrm{cm}^{-1}\right)$ : $3362(\mathrm{Ar}-\mathrm{OH}) 3266(\mathrm{~N}-\mathrm{H})$, 2997 (Ar C-H), $2841\left(-\mathrm{OCH}_{3}\right), 1647(\mathrm{C}=\mathrm{O}), 1597(\mathrm{C}=\mathrm{N}) ;{ }^{1} \mathrm{HNMR}$ $\left(400 \mathrm{MHz}, \mathrm{DMSO}-d_{6}\right) \delta: 3.66\left(\mathrm{~s}, 3 \mathrm{H}, \mathrm{Ar}-\mathrm{OCH}_{3}\right), 6.91-8.07$ $(\mathrm{m}, 12 \mathrm{H}, \mathrm{Ar} \mathrm{C}-\mathrm{H}, \mathrm{HC}=\mathrm{C}), 8.41(\mathrm{~s}, 1 \mathrm{H}, \mathrm{HC}=\mathrm{N}), 9.60(\mathrm{~s}, 1 \mathrm{H}$, Ar-OH), 9.90 (s, 1H, CO-NH), 11.50 (s, 1H, CO-NHN); ${ }^{13} \mathrm{CNMR}$

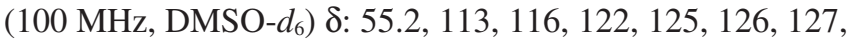
$128,130,133,137,144,148,149,163,166$. EI-MS m/z; 421 $\left(\mathrm{M}^{+}\right)$. Anal. calcd. for $\mathrm{C}_{22} \mathrm{H}_{19} \mathrm{~N}_{3} \mathrm{O}_{4} \mathrm{~S}(\%)$ : C, 62.69; H, 4.54; N, 9.97. Found: C, 62.51; H, 4.34; N, 9.82

2-Benzamido-N'-(3, 4, 5-trimethoxybenzylidene)-3(thiophen-2-yl)acrylohydrazide (4d): Yield: $74 \%$; m.p.: 164$166{ }^{\circ} \mathrm{C}$; IR (KBr, $\left.v_{\max }, \mathrm{cm}^{-1}\right): 3194(\mathrm{~N}-\mathrm{H}), 3060$ (Ar C-H), $2837\left(-\mathrm{OCH}_{3}\right), 1660(\mathrm{C}=\mathrm{O}), 1572(\mathrm{C}=\mathrm{N}) ;{ }^{1} \mathrm{H}$ NMR $(400 \mathrm{MHz}$, DMSO- $\left.d_{6}\right)$ \&: 3.66-3.786 (s, 6H, $\left.\mathrm{Ar}-\mathrm{OCH}_{3}\right), 6.95-8.08(\mathrm{~m}, 14 \mathrm{H}$,
Ar C-H, HC=C), $8.32(\mathrm{~s}, 1 \mathrm{H}, \mathrm{HC}=\mathrm{N}), 9.91(\mathrm{~s}, 1 \mathrm{H}, \mathrm{CO}-\mathrm{NH})$, 11.54 (s, 1H, CO-NH-N); Anal. calcd. for $\mathrm{C}_{24} \mathrm{H}_{23} \mathrm{~N}_{3} \mathrm{O}_{5} \mathrm{~S}(\%)$ : C, 61.53; H, 5.13; N, 8.55. Found: C, 61.70; H, 5.21; N, 8.37.

2-Benzamido-N'-(4-dimethylaminobenzylidene)-3(thiophen-2-yl) acrylohydrazide (4e): Yield: $79 \%$; m.p.: 202$204^{\circ} \mathrm{C}$; IR $\left(\mathrm{KBr}, \mathrm{v}_{\max }, \mathrm{cm}^{-1}\right)$ : $3271(\mathrm{~N}-\mathrm{H}), 3076$ (Ar C-H), 2810 $\left(-\mathrm{CH}_{3}\right), 1653(\mathrm{C}=\mathrm{O}), 1576(\mathrm{C}=\mathrm{N})$; ${ }^{1} \mathrm{H}$ NMR $(400 \mathrm{MHz}$, DMSO$\left.d_{6}\right) \delta: 2.69\left(\mathrm{~s}, 6 \mathrm{H}, \mathrm{N}-\left(\mathrm{CH}_{3}\right)_{2}\right), 6.95-7.97(\mathrm{~m}, 13 \mathrm{H}, \mathrm{ArC}-\mathrm{H}, \mathrm{HC}=\mathrm{C})$, $8.29(\mathrm{~s}, 1 \mathrm{H}, \mathrm{HC}=\mathrm{N}), 9.87(\mathrm{~s}, 1 \mathrm{H}, \mathrm{CO}-\mathrm{NH}), 11.49(\mathrm{~s}, 1 \mathrm{H}, \mathrm{CO}-\mathrm{NH}-$ $\mathrm{N}$ ); Anal. calcd. for $\mathrm{C}_{23} \mathrm{H}_{22} \mathrm{~N}_{4} \mathrm{O}_{2} \mathrm{~S}(\%)$ : C, 67.54; H, 5.44; $\mathrm{N}$, 12.60. Found: C, 67.83; H, 5.52; N, 12.80 .

2-Benzamido-N'-(4-chlorobenzylidene)-3-(thiophen-2yl) acrylohydrazide (4f): Yield: $77 \%$; m.p.: $238-240{ }^{\circ} \mathrm{C}$; IR $\left(\mathrm{KBr}, v_{\max }, \mathrm{cm}^{-1}\right): 3269(\mathrm{~N}-\mathrm{H}), 3062(\mathrm{Ar} \mathrm{C}-\mathrm{H}), 1662(\mathrm{C}=\mathrm{O})$, $1571(\mathrm{C}=\mathrm{N}) ;{ }^{1} \mathrm{H}$ NMR $\left(400 \mathrm{MHz}, \mathrm{DMSO}-d_{6}\right) \delta: 7.16(\mathrm{~s}, 1 \mathrm{H}$, $\mathrm{HC}=\mathrm{C}), 7.07-8.21(\mathrm{~m}, 13 \mathrm{H}, \mathrm{Ar} \mathrm{C}-\mathrm{H}, \mathrm{HC}=\mathrm{C}), 8.40(\mathrm{~s}, 1 \mathrm{H}$, $\mathrm{HC}=\mathrm{N}), 9.92(\mathrm{~s}, 1 \mathrm{H}, \mathrm{CO}-\mathrm{NH}), 11.51$ (s, 1H, CO-NH-N); Anal. calcd. for $\mathrm{C}_{21} \mathrm{H}_{18} \mathrm{~N}_{3} \mathrm{O}_{2} \mathrm{SCl}(\%)$ : C, 61.37; $\mathrm{H} ; 4.16 ; \mathrm{N}, 9.64$. Found: C, 63.25; H; 4.34; N, 9.76.

2-Benzamido-N'-(4-nitrobenzylidene)-3-(thiophen-2yl) acrylohydrazide (4g): Yield: $80 \%$; m.p.: 246-248 ${ }^{\circ} \mathrm{C}$; IR $\left(\mathrm{KBr}, \mathrm{v}_{\max }, \mathrm{cm}^{-1}\right): 3268(\mathrm{~N}-\mathrm{H}), 3061(\mathrm{Ar} \mathrm{C}-\mathrm{H}), 1655(\mathrm{C}=\mathrm{O})$, $1568(\mathrm{C}=\mathrm{N}), 1525,1317\left(\mathrm{NO}_{2}\right)$; ${ }^{1} \mathrm{H} \mathrm{NMR}(400 \mathrm{MHz}, \mathrm{DMSO}-$ $\left.d_{6}\right) \delta: 7.14-8.30(\mathrm{~m}, 13 \mathrm{H}, \mathrm{Ar} \mathrm{C}-\mathrm{H}, \mathrm{HC}=\mathrm{C}), 8.54(\mathrm{~s}, 1 \mathrm{H}, \mathrm{HC}=\mathrm{N})$, 9.98 (s, 1H, CO-NH), 11.80 (s, 1H, CO-NH-N); Anal. calcd. for $\mathrm{C}_{21} \mathrm{H}_{16} \mathrm{~N}_{4} \mathrm{O}_{4} \mathrm{~S}(\%)$ : C, 59.87; $\mathrm{H}, 4.06, \mathrm{~N}, 13.55$ Found: $\mathrm{C}$, $59.54 ; \mathrm{H}, 4.25 ; \mathrm{N}, 13.62$.

2-Benzamido-3-(thiophen-2-yl)-N'-[(thiophen-2-yl) methylene]acrylohydrazide (4h): Yield: $82 \%$; m.p.: 228$230{ }^{\circ} \mathrm{C}$; IR (KBr, $\left.v_{\max }, \mathrm{cm}^{-1}\right): 3273(\mathrm{~N}-\mathrm{H}), 3026$ (Ar C-H), $1659(\mathrm{C}=\mathrm{O}), 1542(\mathrm{C}=\mathrm{N}) ;{ }^{1} \mathrm{H}$ NMR $\left(400 \mathrm{MHz}, \mathrm{DMSO}-d_{6}\right) \delta$ : 7.09-8.06 (m, 12H, Ar C-H, HC=C), $8.08(\mathrm{~s}, 1 \mathrm{H}, \mathrm{HC}=\mathrm{N}), 9.90$ (s, 1H, CO-NH), 11.51 (s, 1H, CO-NH-N); Anal. calcd. for $\mathrm{C}_{19} \mathrm{H}_{15} \mathrm{~N}_{3} \mathrm{O}_{2} \mathrm{~S}_{2}$ (\%): C, 59.82; H, 3.96; N, 11.02. Found: $\mathrm{C}$, $58.53 ; \mathrm{H}, 3.65 ; \mathrm{N}, 11.35$.

2-Benzamido-N'-[(pyridin-4yl)methylene]-3-(thiophen2-yl)acrylohydrazide (4i): Yield: $78 \%$; m.p.: 185-187 ${ }^{\circ} \mathrm{C}$; IR $\left(\mathrm{KBr}, \mathrm{v}_{\max }, \mathrm{cm}^{-1}\right): 3223(\mathrm{~N}-\mathrm{H}), 3043(\mathrm{Ar} \mathrm{C}-\mathrm{H}), 1645(\mathrm{C}=\mathrm{O})$, $1543(\mathrm{C}=\mathrm{N}) ;{ }^{1} \mathrm{H}$ NMR $\left(400 \mathrm{MHz}, \mathrm{DMSO}-d_{6}\right) \delta: 7.10-8.59(\mathrm{~m}$, 13H, Ar C-H, HC=C), 8.38 (s, 1H, HC=N), 9.94 (s, 1H, CO$\mathrm{NH}$ ), 11.82 (s, 1H, CO-NH-N); Anal. calcd. for $\mathrm{C}_{20} \mathrm{H}_{16} \mathrm{~N}_{4} \mathrm{O}_{2} \mathrm{~S}$ (\%): C, 63.81; H, 4.28; N, 14.88. Found: C, 63.49; H, 4.41; N, 14.72 .

2-Benzamido-N'-(indol-3-yl-methylene)-3-(thiophen-2yl)acrylohydrazide (4j): Yield: $75 \%$; m.p.: $235-237^{\circ} \mathrm{C}$; IR $\left(\mathrm{KBr}, \mathrm{v}_{\max }, \mathrm{cm}^{-1}\right): 3475$ (N-H of Ind), $3252(\mathrm{~N}-\mathrm{H}), 3053(\mathrm{Ar}$ $\mathrm{C}-\mathrm{H}), 1673(\mathrm{C}=\mathrm{O}), 1572(\mathrm{~N}=\mathrm{C}) ;{ }^{1} \mathrm{H}$ NMR $\left(400 \mathrm{MHz}, \mathrm{DMSO}-d_{6}\right)$

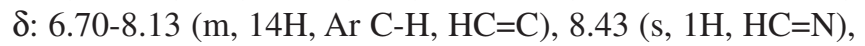
10.81 (s, 1H, CO-NH-), 10.21 (s, 1H, NH of Ind), 11.09 (s, $1 \mathrm{H}, \mathrm{CO}-\mathrm{NH}-\mathrm{N}) ;{ }^{13} \mathrm{C}$ NMR $\left(100 \mathrm{MHz}, \mathrm{DMSO}-d_{6}\right) \delta: 111,112$, 115, 120, 126, 127, 128, 129, 130, 132, 135, 137, 144, 162, 165. EI-MS $m / z ; 414\left(\mathrm{M}^{+}\right)$; Anal. calcd. for $\mathrm{C}_{23} \mathrm{H}_{18} \mathrm{~N}_{4} \mathrm{O}_{2} \mathrm{~S}(\%)$ : C, 66.65; H, 4.38; N, 13.52. Found: C, 66.24; H, 4.68; N, 13.49.

2-(Benzamido)-N'-(2-oxoindolin-3-ylidene)-3-(thiophen2-yl)acrylohydrazide (4k): Yield: $69 \%$; m.p.: 231-233 ${ }^{\circ} \mathrm{C}$; IR $\left(\mathrm{KBr}, \mathrm{v}_{\max }, \mathrm{cm}^{-1}\right): 3470(\mathrm{~N}-\mathrm{H}$ of Isa), $3238(\mathrm{~N}-\mathrm{H}), 3063$ (Ar C-H), 1725, 1675 (C=O of isa, $\mathrm{C}=\mathrm{O}$ of $\mathrm{CONH}) ;{ }^{1} \mathrm{H}$ NMR $\left(400 \mathrm{MHz}, \mathrm{DMSO}-d_{6}\right) \delta: 6.6-8.14(\mathrm{~m}, 13 \mathrm{H}, \mathrm{Ar} \mathrm{C}-\mathrm{H}, \mathrm{HC}=\mathrm{C})$, 
10.78 (s, 1H, NH of Isa), 10.07 (s, 1H, CO-NH), 11.08 (s, 1H, CO-NH-N); Anal. calcd. for $\mathrm{C}_{22} \mathrm{H}_{16} \mathrm{~N}_{4} \mathrm{O}_{3} \mathrm{~S}(\%)$ : C, 63.45; H, 3.87; N, 13.45. Found: C, 63.54; H, 3.83; N, 13.59.

2-(Benzamido)-N'-[(naphthalen-3-yl)methylene]-3(thiophen-2-yl)acrylohydrazide (4l): Yield: $70 \%$; m.p.: 181$183{ }^{\circ} \mathrm{C}$; IR (KBr, $\left.v_{\max }, \mathrm{cm}^{-1}\right): 3186(\mathrm{~N}-\mathrm{H}), 3049$ (Ar C-H), $1647(\mathrm{C}=\mathrm{O}), 1576(\mathrm{C}=\mathrm{N}) ;{ }^{1} \mathrm{H}$ NMR $\left(400 \mathrm{MHz}, \mathrm{DMSO}-d_{6}\right) \delta$ : $7.16(\mathrm{~s}, 1 \mathrm{H}, \mathrm{HC}=\mathrm{C}), 7.10-8.11(\mathrm{~m}, 16 \mathrm{H}, \mathrm{Ar} \mathrm{C}-\mathrm{H}, \mathrm{HC}=\mathrm{C}), 8.7$ (s, 1H, HC=N), 9.95 (s, 1H, CO-NH), 11.63 (s, 1H, CO-NH$\mathrm{N}$ ); Anal. calcd. for $\mathrm{C}_{25} \mathrm{H}_{19} \mathrm{~N}_{3} \mathrm{O}_{2} \mathrm{~S}(\%)$ : C, 70.57; H, 4.50; N, 9.88. Found: C, 70.19; H, 4.68; N, 9.85.

in vivo Antiinflammatory activity: The in vivo antiinflammatory activity of all the title compounds was evaluated using carrageenan-induced hind paw edema test in male albino rats $(150-180 \mathrm{~g})$ of Wistar strain at $100 \mathrm{mg} / \mathrm{kg}$ body weight [17]. The rats were divided into groups of six animals. Control group received $0.5 \%$ sodium carboxymethyl cellulose, the standard group received standard drug indomethacin $5 \mathrm{mg} / \mathrm{kg}$ body weight and the test groups received the synthesized compounds at the dose of $100 \mathrm{mg} / \mathrm{kg}$ body weight. The volume of the injected paw was measured by plethysmograph immediately after carrageenan injection. The paw volume was again measured after $3 \mathrm{~h}$. A mark was made at the lateral maleolus and the foot was dipped to the same distance into the arm of plethysmograph. Average edema volumes for test compound treated and positive control rats were compared statistically and expressed as the pre cent edema inhibition, which was calculated using the formula.

$$
\text { Inhibition }(\%)=100\left(1-\mathrm{V}_{\mathrm{t}} / \mathrm{V}_{\mathrm{c}}\right)
$$

where, $\mathrm{V}_{\mathrm{c}}=$ volume of edema in the control group and $\mathrm{V}_{\mathrm{t}}=$ volume of edema in the treated group. Statistical significance of the results was tested by Dunnet's test.

Analgesic activity by acetic acid induced writhing method: This method was based on acetic acid-induced writhings in mice [18]. Albino mice of both sex (18-25 g) were used. The animals were divided into groups consisting of six mice each and control group received $0.5 \%$ sodium carboxy methylcellulose. Test groups were dosed with the test compounds and the standard group with aspirin, at a dose of $100 \mathrm{mg} / \mathrm{kg}$ p.o., $1 \mathrm{~h}$ before intraperitoneal injection of $0.6 \%$ acetic acid $(10 \mathrm{~mL} /$ $\mathrm{kg}$ ). Mice were observed for the total number of writhes for a period of $15 \mathrm{~min}$ beginning $5 \mathrm{~min}$ after the acetic acid injection and the total number of writhes was recorded. The mean value of writhes for each group was calculated and compared statistically with the vehicle treated control group. Results were expressed in terms of percent inhibition of the number of writhes, which was calculated using the formula:

$$
\text { Inhibition }(\%)=100\left(1-\mathrm{W}_{\mathrm{t}} / \mathrm{W}_{\mathrm{c}}\right)
$$

where, $\mathrm{W}_{\mathrm{c}}$ number of writhes for the control group and $\mathrm{W}_{\mathrm{t}}$ number of writhes for the treated group. Statistical significance of the results was tested by Dunnet's test.

Molecular docking: Molecular docking of compounds (4a-l) with 3D X-ray crystal structure of human COX-2 retrieved from the Protein data bank (PDB code: 5F19) was imported in to maestro $\mathrm{v}$ 9.0. All the bound water, ligands were eliminated from the protein and receptor grid of $20 \times 20 \times 20 \AA$ was generated around the active site using PyMOL. The 3D structure of aforementioned compounds (4a-l) were drawn using chem 3D ultra 12.0 software (Cambridge soft corporation) and the druglikness scores for all ligands were evaluated with the help of Lipinski filter. Subsequently, the optimized ligands and standard drug were embedded in to the generated grid of human COX-2 protein to access their binding affinities and dock score using GLIDE XP docking score method.

\section{RESULTS AND DISCUSSION}

2-Benzamido-N'-(substituted benzylidene)-3-(thiophen2-yl)acrylohydrazides (4a-1) were synthesized by the nucleophilic addition of 2-(benzamido)-3-(thiophen-2-yl)acrylohydrazide (3) with aromatic aldehydes and simultaneous elimination of water by microwave irradiation (160 watts) under acidic conditions with less reaction time (30-180 s), high purity and yields (68-82\%), depicted in Scheme-I. Compound 3 has been synthesized from intermediate compound $\mathbf{2}$ by the action of hydrazine hydrate, act as strong nucleophile attacks the oxazole ring at highly susceptible carbonyl site. Compound 2 was prepared according to literature procedure. The IR spectral data of title compounds 4a-l showed strong bands between $3475-3186 \mathrm{~cm}^{-1}$ and $1675-1637 \mathrm{~cm}^{-1}$ due to the presence of $\mathrm{NH}$ and $\mathrm{C}=\mathrm{O}$ peaks, respectively and also appearance of two more bands between $3103-2997 \mathrm{~cm}^{-1}, 1577-1542 \mathrm{~cm}^{-1}$ region indicates the presence of aromatic $\mathrm{C}-\mathrm{H}, \mathrm{N}=\mathrm{CH}$ groups in title compounds. This was further confirmed by ${ }^{1} \mathrm{HNMR}$ spectra explains the appearance of a new singlet around $\delta 8.0$ region (which corresponds to $\mathrm{CH}=\mathrm{N}$ proton), in the place of singlet at $\delta 4.45$ (due to free $\mathrm{NH}_{2}$ in compound 3 ) clearly indicates the formation of title compounds. This was supported by the appearance of singlet between of $\delta 11.09-11.82$ region due to the protons of -CONH-N= group (hydrazone) and showed a multiplet between $\delta 6.70-8.21$ regions indicates the shielding and deshielding of aromatic protons by substituents on ring. Additional support for the structures of title compounds was provided by ${ }^{13} \mathrm{C}$ NMR spectra reveals two peaks around $\delta 163-166$ and a peak around $\delta 55$ assigned for carbonyl group of amide and methoxy group respectively. The peaks resonated between $\delta 111-149$ is due to the presence of aromatic/hero-aromatic carbons and also appearance of signal around $\delta 140$ indicates the presence of $\mathrm{C}=\mathrm{N}$ linkage. All the title compounds conformed by the appearance of molecular ion peaks between $m / z$ 375-421.

Antiinflammatory activity: All the compounds (4a-l) evaluated for the antiinflammatory activity by carrageenan induced rat paw edema method and the activity profile clearly indicates the type of substitution at the hydrazone end of the molecule significantly alters the activity follows such as fused heteroaryl $>$ phenyl with EDG $>$ phenyl > polycyclic moiety $>$ six membered hetero aryl $>$ phenyl with EWG $>$ five membered heteroaryl substitutions (Table-1). It is also observed that among all compound $(\mathbf{4 j})$ elicited superior activity than standard, is due to the presence of additional electron rich heterocyclic ring within the molecule [12] followed by compounds (4c and $\mathbf{4 d}$ ) due to the presence of more number of EDGs at the hydrazide end of the molecule responsible for the enhanced activity [19]. It is important to note, as increase the number of EDGs on phenyl ring enhance the activity $(\mathbf{4 d}>\mathbf{4 b})$ and this observation gave additional support for the importance of EDGs towards the activity. 
<smiles>[AlH2][AsH2]</smiles>

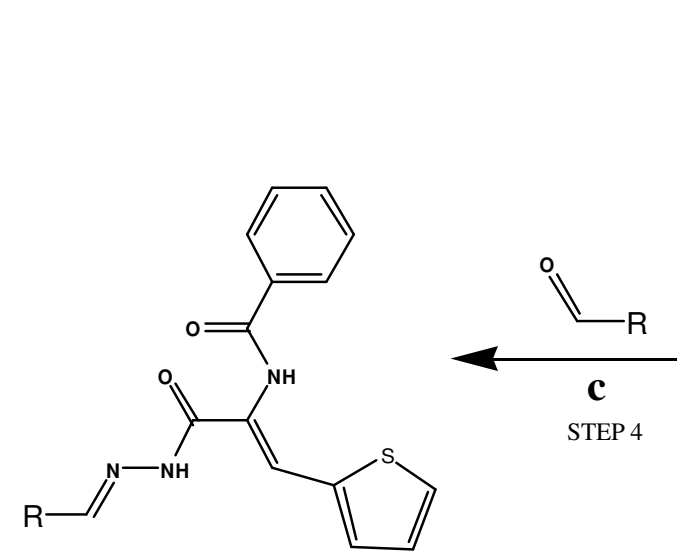

$(4 \mathbf{a}-41)$<smiles>O=C(O)CNC(=O)c1ccccc1</smiles>

(1)<smiles>O=Cc1cccs1</smiles>
STEP 2

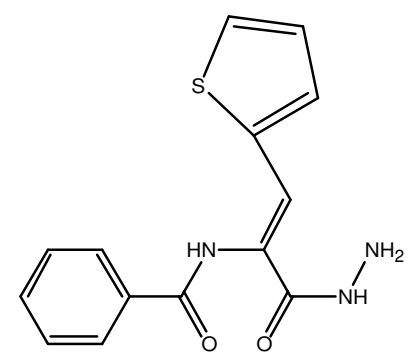

(3)

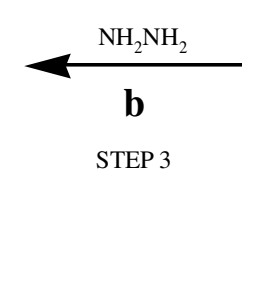

(2)

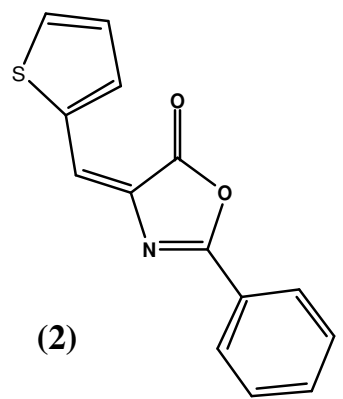

(a): $\left(\mathrm{CH}_{3} \mathrm{CO}\right)_{2} \mathrm{O}$ /zinc oxide and ethanol; (b) : Absolute ethanol, stirring; (c): $\mathrm{MW}$ at $160 \mathrm{~W}$

R=Phenyl (4a); 4-Methoxy phenyl (4b); 4-Hydroxy, 3-methoxy phenyl (4c); 3,4,5-Trimethoxy phenyl (4d); 4-Dimethyl amino phenyl(4e); 4-Chloro phenyl (4f); 4-Nitro phenyl (4g); Thiophen-2-yl (4h); Pyridin-4-yl (4i); Indol-3-yl (4j); Isatin-3-yl (4k); Naphthalen-2-yl (4l)

Scheme-I: General sequence of reactions for the synthesis of compounds (4a-l)

\begin{tabular}{|c|c|c|c|c|c|c|c|}
\hline \multirow{3}{*}{$\begin{array}{l}\text { Compd. } \\
\text { No. }\end{array}$} & \multicolumn{7}{|c|}{$\begin{array}{l}\text { TABLE-1 } \\
\text { in vivo ANTI-INFLAMMATORY ACTIVITY AND MOLECULAR DOCKING SCORES OF TITLE COMPOUNDS (4a-l) }\end{array}$} \\
\hline & \multicolumn{2}{|c|}{ in vivo } & \multicolumn{5}{|c|}{ Molecular docking } \\
\hline & $\begin{array}{c}\text { Edema } \\
\text { volume }( \pm \mathrm{SD})^{\mathrm{a}}\end{array}$ & $\begin{array}{c}\text { Edema } \\
\text { inhibition }(\%)^{\mathrm{d}}\end{array}$ & NHB & HBD (̊) & AA & DS & $\mathrm{BE}(\mathrm{Kcal} / \mathrm{mol})$ \\
\hline $4 a$ & $0.17(0.14)^{\mathrm{c}}$ & $67 *$ & 2 & $2.17,2.06$ & GLN203, HIE388 & -7.58 & -58.07 \\
\hline $4 b$ & $0.15(0.04)^{b}$ & $69 *$ & - & - & - & -7.02 & -50.10 \\
\hline $4 c$ & $0.13(0.02)^{\mathrm{c}}$ & $74 *$ & 2 & $2.00,2.31$ & GLN454 & -8.96 & -75.15 \\
\hline $4 d$ & $0.13(0.02)^{b}$ & $73 *$ & 1 & 2.08 & GLN454 & -9.58 & -75.72 \\
\hline $4 e$ & $0.25(0.05)^{\mathrm{b}}$ & 48 & 1 & 2.63 & HIE388 & -6.87 & -73.46 \\
\hline 4f & $0.26(0.17)^{b}$ & 46 & 1 & 2.06 & HIE388 & -7.08 & -81.88 \\
\hline $4 \mathrm{~g}$ & $0.31(0.25)^{\mathrm{c}}$ & 39 & 1 & 2.43 & HIE388 & -6.63 & -72.72 \\
\hline $4 h$ & $0.35(0.22)^{b}$ & 27 & 1 & 2.21 & HIE388 & -6.97 & -56.03 \\
\hline $4 \mathbf{i}$ & $0.25(0.25)^{\mathrm{c}}$ & 51 & 1 & 2.04 & HIS214 & -7.92 & -69.86 \\
\hline $4 \mathbf{j}$ & $0.12(0.01)^{\mathrm{c}}$ & $76^{*}$ & 1 & 2.23 & HIE388 & -9.77 & -70.01 \\
\hline $4 k$ & $0.15(0.09)^{\mathrm{c}}$ & $70 *$ & 2 & 2.01 & ASN382, HIE388 & -7.94 & -70.16 \\
\hline 41 & $0.16(0.06)^{b}$ & $66^{*}$ & - & - & - & -7.20 & -64.69 \\
\hline Std & $0.14(0.02)^{\mathrm{c}}$ & $73 *$ & 0 & - & - & -7.18 & -37.19 \\
\hline \multicolumn{8}{|c|}{$\begin{array}{l}\text { Significant levels } * \mathrm{p}<0.001 \text { by Dunnet's t- test; }{ }^{\mathrm{a}} \text { Edema volume was measured } 3 \mathrm{~h} \text { after carrageenan injection and expressed as mean } \pm \text { standard } \\
\text { deviation; }{ }^{b} \text { Control edema volume }=0.48 \pm 0.04 ; \text {; }{ }^{c} \text { Control edema volume }=0.52 \pm 0.01 ;{ }^{d} \text { At } 100 \mathrm{mg} / \mathrm{kg} \text { (p.o) per cent edema inhibition was } \\
\text { calculated by comparing edema volume with that of the respective control animals; NHB: No of hydrogen bonds; HD: Hydrogen bond distance; } \\
\text { AA: Amino acid; DS: Docking score; BE: Binding free energy }\end{array}$} \\
\hline
\end{tabular}

Molecular docking: All the title compounds (4a-l) were docked into COX-2 (PDB code: 5F19) protein. Docking studies reveals, the aromatic substitution at the hydrazide end and thiophene moiety responsible for fitting of ligand in to the hydrophobic cavity of target and also the carbonyl group, substitutions on the aromatic ring responsible for hydrogen bond formation with the target illustrated in Fig. 1. The results (Table-1) revealed that all the compounds showed good binding affinity towards the target except few $(\mathbf{4 e}, \mathbf{4 g}, \mathbf{4 h})$ and compound (4j: -9.77) showed highest docking score than standard (-0.718), forms one hydrogen bond (2.23 $\AA$ ) with the HIS 388 amino acid present at the active site of target protein (Figs. 2 and 3). It is interesting to note that all the compounds bind with the target protein in cis conformation except $\mathbf{4 a}, \mathbf{4 c}, \mathbf{4 d}$ (trans conformation) and form hydrogen bond between $\mathrm{C}=\mathrm{O}$ of ligand with the HIE 388 amino acid of target protein. And also compounds (4c and $\mathbf{4 d}$ ) form two hydrogen bond interactions with GLN454 amino acid of target protein is due to the terminal EDGs, which influences the biological activity significantly.

Analgesic activity: Further the study was extended by screening of active antiinflammatory compounds $(\mathbf{4 a}, \mathbf{4 b}, \mathbf{4 c}$, 


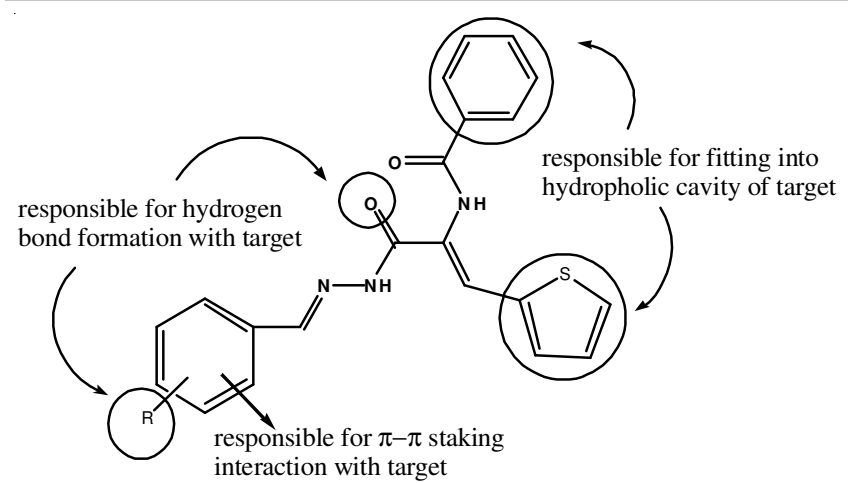

Fig. 1. Interaction sites of title compounds with $\mathrm{COX}-2$ protein

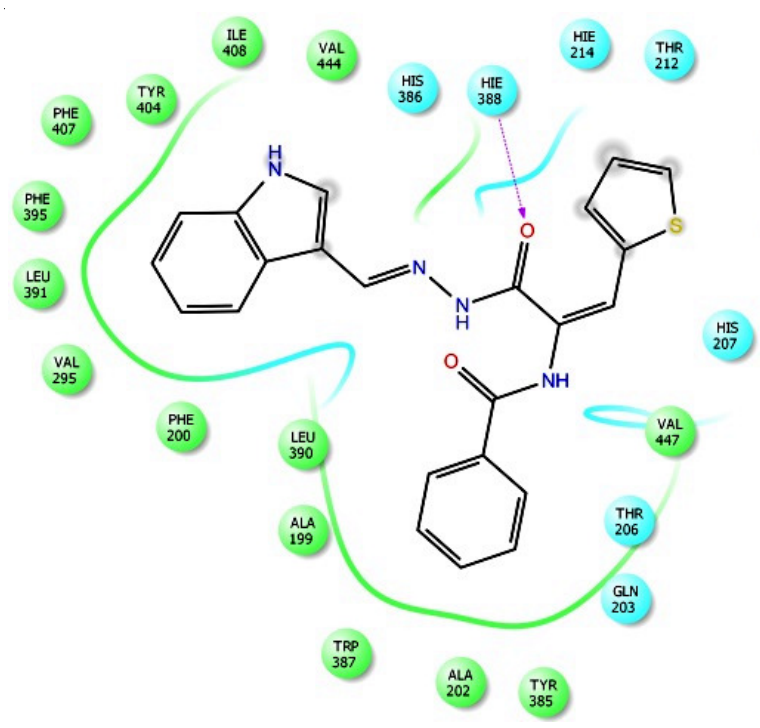

Fig. 2. Interaction of $\mathbf{4 j}$ with COX-2

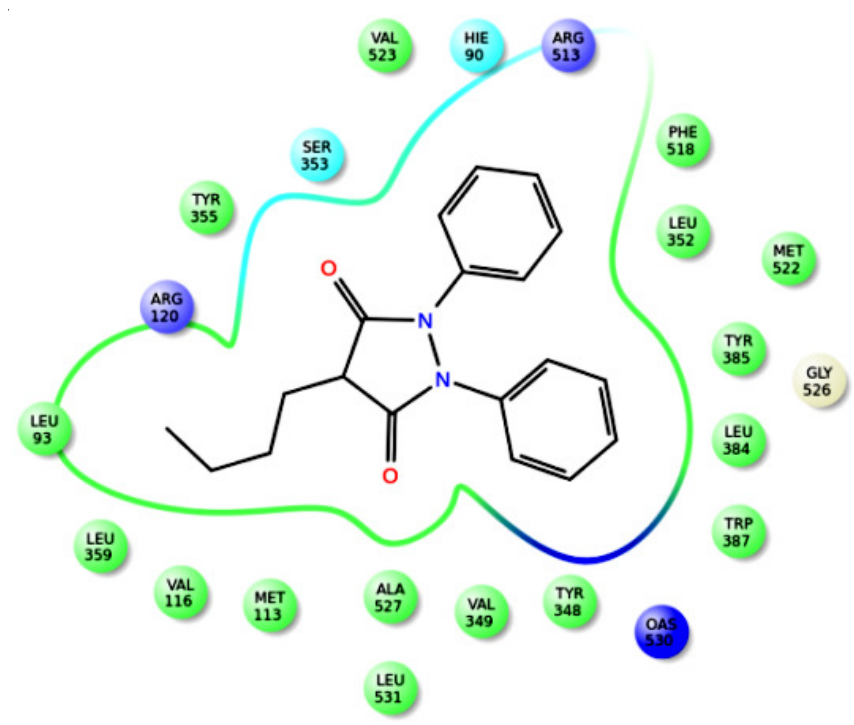

Fig. 3. Interaction of compound standard with COX-2

$\mathbf{4 d}, \mathbf{4 j}$ and $\mathbf{4 k}$ ) for analgesic activity by using acetic acid induced writhing test. The analgesic data (Table-2) of title compounds

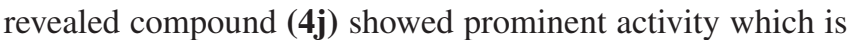
higher than standard (62\%) followed by compound $\mathbf{4 k}, \mathbf{4 c}$ showed moderate activity and remaining all are less active than standard.

\begin{tabular}{ccc}
\multicolumn{4}{c}{ TABLE-2 } \\
in vivo ANALGESIC ACTIVITY OF COMPOUNDS 4a-I
\end{tabular}

Significant levels $* \mathrm{p}<0.001$ by Dunnet's t- test; ${ }^{\mathrm{a}}$ Number of writhes in 15 min beginning 5 min after acetic acid injection and expressed as mean \pm standard deviation; ${ }^{\mathrm{b}}$ Control number of writhes $=78( \pm 2)$; ${ }^{\mathrm{c}} \mathrm{At}$ $100 \mathrm{mg} / \mathrm{kg}$ Per cent writhing inhibition was calculated by comparing number of writhes with that of the respective control animals.

\section{Conclusion}

In conclusion, we have synthesized the title compounds by using microwave technique with less reaction time, good yields, screened for the antiinflammatory and analgesic activity. Among all the compounds, compound $\mathbf{4 j}$ emerged as a lead compound have both antiinflammatory and analgesic activity which is supported by molecular docking studies and also need further studies to optimize the molecule as effective drug candidate.

\section{REFERENCES}

1. M.C. Allison, A.G. Howatson, C.J. Torrance, F.D. Lee and R.I. Russell, N. Engl. J. Med., 327, 749 (1992); https://doi.org/10.1056/NEJM199209103271101.

2. P. McGettigan and D. Henry, JAMA, 296, 1633 (2006); https://doi.org/10.1001/jama.296.13.jrv60011.

3. A.M. Pieczonka, A. Strzelczyk, B. Sadowska, G. Mloston and P. Staczek, Eur. J. Med. Chem., 64, 389 (2013); https://doi.org/10.1016/j.ejmech.2013.04.023.

4. M. Gokce, S. Utku and E. Kupeli, Eur. J. Med. Chem., 44, 3760 (2009); https://doi.org/10.1016/j.ejmech.2009.04.048.

5. C.M. Moldovan, O. Oniga, A. Parvu, B. Tiperciuc, P. Verite, A. Pirnau, O. Crisan, M. Bojita and R. Pop, Eur. J. Med. Chem., 46, 526 (2011); https://doi.org/10.1016/j.ejmech.2010.11.032.

6. E. Vavrikova, S. Polanc, M. Kocevar, K. Horvati, S. Bosze, J. Stolarikova, K. Vavrova and J. Vinsova, Eur. J. Med. Chem., 46, 4937 (2011); https://doi.org/10.1016/j.ejmech.2011.07.052.

7. J.D. Bhatt, C.J. Chudasama and K.D. Patel, Bioorg. Med. Chem., 23, 7711 (2015); https://doi.org/10.1016/j.bmc.2015.11.018.

8. A.T. Mavrova, D. Wesselinova, N. Vassilev and J.A. Tsenov, Eur. J. Med. Chem., 63, 696 (2013); https://doi.org/10.1016/j.ejmech.2013.03.010.

9. Y. Jin, Z. Tan, M. He, B. Tian, S. Tiang, I. Hawlett and M. Yang, Bioorg. Med. Chem., 18, 2135 (2010); https://doi.org/10.1016/j.bmc.2010.02.003.

10. P. Hernández, M. Cabrera, M.L. Lavaggi, L. Celano, I. Tiscornia, T. Rodrigues da Costa, L. Thomson, M. Bollati-Fogolín, A.L.P. Miranda, L.M. Lima, E.J. Barreiro, M. González and H. Cerecetto, Bioorg. Med. Chem., 20, 2158 (2012); https://doi.org/10.1016/j.bmc.2012.01.034.

11. S.M. Siddiqui, A. Salahuddin and A. Azam, Eur. J. Med. Chem., 49, 411 (2012); https://doi.org/10.1016/j.ejmech.2012.01.030.

12. A.R. Todeschini, A.L.P. de Miranda, K.C.M. da Silva, S.C. Parrini and E.J. Barreiro, Eur. J. Med. Chem., 33, 189 (1998); https://doi.org/10.1016/S0223-5234(98)80008-1.

13. F. Haviv, J.D. Ratajczyk, R.W. DeNet, F.A. Kerdesky, R.L. Walters, S.P. Schmidt, J.H. Holms, P.R. Young and G.W. Carter, J. Med. Chem., 31, 1719 (1988); https://doi.org/10.1021/jm00117a010. 
14. G. Rajitha, K.V.S.R.G. Prasad, A. Umamaheswari, D. Pradhan and K. Bharathi, Med. Chem. Res., 23, 5204 (2014); https://doi.org/10.1007/s00044-014-1091-0.

15. G. Fareed, N. Afza, A. Versiani, N. Fareed, R. Mughal, A. Kalhoro, L. Iqbal and M. Lateef, J. Serb. Chem. Soc., 78, 1127 (2013); https://doi.org/10.2298/JSC120917126F.

16. G. Rajitha, N. Saideepa and P. Praneetha, Indian J. Chem., 50B, 729 (2011)
17. C.A. Winter, E.A. Risley and G.W. Nuss, Proc. Soc. Exp. Biol. Med., 111, 544 (1962); https://doi.org/10.3181/00379727-111-27849.

18. R. Koster, M. Anderson and E.J. De Beer, Federation Proceed., 18, 412 (1959).

19. J.R. Dimmock, S.C. Vashishtha and J.P. Stables, Eur. J. Med. Chem., 35, 241 (2000);

https://doi.org/10.1016/S0223-5234(00)00123-9. 